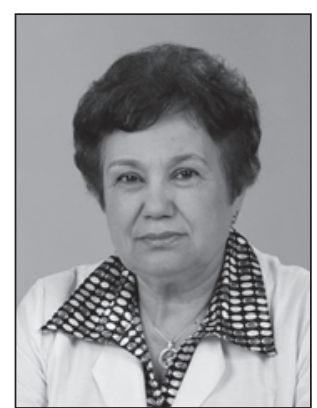

ДєДУХ Н.В.,

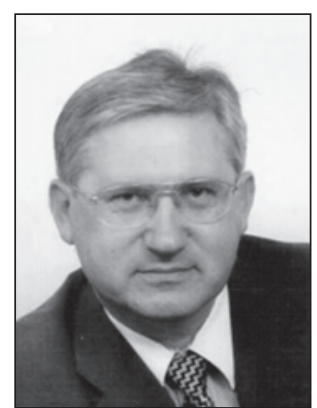

РАДЧЕНКО В.А.,

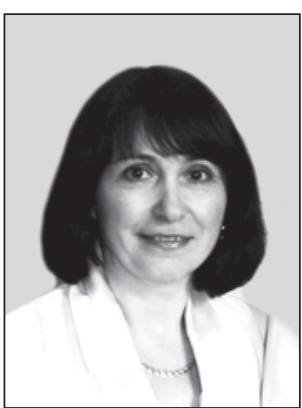

БЕНГУС Л.М.,
МАЛИШКІНА С.В.

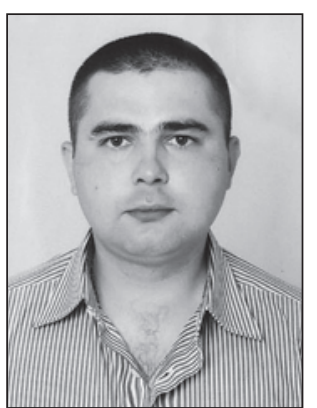

шимон м.в.

\title{
МОРФОЛОГІЯ ПЕРИФЕРИЧНОГО НЕРВА ЩУРІВ В ЗОНІ ТРАНСПЛАНТАЦІї АВТОЛОГІЧНОГО ДРАГЛИСТОГО ЯДРА ПІСЛЯ ТЕРАПІї АДАЛІМУМАБОМ
}

Резюме. Морфологічний аналіз структурної організації великогомілкової гілки сідничного нерва щурів у зоні трансплантації автологічного драглистого ядра після проведеного лікування адалімумабом показав, що у тварин спостерігались зниження інтенсивності запального процесу в епі-, пері-, ендоневральних тканинах і значно краще збереження ультраструктури мієлінових і безмієлінових волокон у периферичному нерві порівняно з щурами контрольної нелікованої групи.

Ключові слова: периферичний нерв, драглисте ядро, трансплантація, адалімумаб, метаболічні показники сироватки крові.

\section{Вступ}

Сучасні уявлення щодо генезу грижі міжхребцевого диска свідчать, що одним із ключових моментів у каскаді подій цього процесу є експресія компонентами грижі прозапальних цитокінів, серед яких провідне місце посідає фактор некрозу пухлини альфа (ФНП- $\alpha)$ [1]. Руйнівний вплив цих цитокінів спостерігається навіть без наявності механічної дії, яку спричиняє грижа, на нервові корінці.

Маніфестація больового синдрому в пацієнтів із грижами міжхребцевого диска має місце при поєднанні явищ компресії нервових корінців та хімічних компонентів, продукованих грижею [2-4]. Враховуючи наведені дані, видається актуальним застосування в комплексі лікувальних заходів у таких пацієнтів речовин, що блокують біосинтез цитокінів запалення, зокрема фактора некрозу пухлини альфа. Одним із таких препаратів біологічної терапії є хуміра, що належить до нового класу терапевтичних агентів, які ефективно зарекомендували себе при лікуванні хронічних запальних захворювань [5]. Діючою речовиною хуміри є адалімумаб, що являє собою повністю людські рекомбінантні моноклональні антитіла до ФНП- $\alpha$ [6]. Адалімумаб має високу афінність до розчинної трансмембранної форми ФНП- $\alpha$ та пригнічує його зв'язування з власним рецептором. Проте серед літературних джерел ми не зустріли експериментальних робіт, де б досліджувалась дія адалімумабу на змодельовану грижу міжхребцевого диска.

Мета роботи: дослідити зміни структурної організації периферичного нерва щурів у ділянці трансплантації автологічного драглистого ядра після консервативного лікування тварин адалімумабом.

\section{Матеріал та методи дослідження}

Автологічне драглисте ядро, вилучене із міжхребцевого диска хвостового відділу щурів, було трансплантоване на великогомілкову гілку сідничного нерва (ВГГСН). Техніка виконання хірургічної операції подана в нашій попередній статті [7].

Проведено 4 серії експериментів.

- 1-ша серія (контроль 1) - хибнооперовані тварини (9 щурів);

- 2-га серія (контроль 2) - тварини з трансплантованим драглистим ядром на ВГГСН (15 щурів);

- 3-тя серія (дослід 1) - тварини з трансплантованим драглистим ядром на ВГГСН, одноразово проліковані адалімумабом (15 тварин);

(C) Дєдух Н.В., Радченко В.А., Бенгус Л.М., Малишкіна С.В., Шимон М.В., 2013

(C) «Біль. Суглоби. Хребет», 2013

(c) Заславський О.Ю., 2013 
- 4-та серія (дослід 2) - тварини із трансплантованим драглистим ядром на ВГГСН, дворазово проліковані адалімумабом (10 щурів).

Контролем до експериментальної моделі слугували хибнооперовані щури, яким аналогічно дослідним тваринам розрізали шкіру, тупим распатором розводили м'язи, відкривали та відокремлювали від м'язів ВГГСН. Рану ушивали. Вилучали й елімінували драглисте ядро із $\mathrm{Cc}_{\mathrm{IV}}-\mathrm{Cc}_{\mathrm{V}}-$ хвостового рухового сегмента хребта щурів.

Лікування адалімумабом (препарат хуміра) виконували введенням препарату у вигляді підшкірних ін'єкцій (1,26 мг на 100 г живої маси) одноразово (на 1-шу добу після моделювання) та дворазово (на 1-гу та 3-тю добу після моделювання).

Експериментальне моделювання на щурах виконували, додержуючись нормативів біоетики [8, 9]. Тварин виводили з експерименту на 3-тю, 7-му та 15-ту добу.

Матеріалом для дослідження слугували фрагменти м'язів з імплантованим під нерв драглистим ядром. Для гістологічних досліджень матеріал обробляли згідно з методами гістологічної проводки та поміщали в целоїдин [10]. Гістологічні зрізи фарбували гематоксиліном, еозином та пікрофуксином за Ван Гізоном [10]. Пофарбовані зрізи аналізували в мікроскопі Primostar. Фотовідбитки гістологічних препаратів отримували за допомогою цифрової фотокамери Canon EOS-300D.

Препарати для електронної мікроскопії виготовляли згідно з рекомендаціями Б. Уїклі [11]. Диференційне забарвлення напівтонких зрізів проводили $1 \%$ розчином метиленового синього та $1 \%$ розчином основного фуксину. Ультратонкі зрізи контрастували цитратом свинцю та уранілацетатом за Reynolds [12]. Ультраструктурний аналіз здійснювали за допомогою трансмісійного електронного мікроскопа ЕМВ-100БР.

Морфометричний аналіз застосували для визначення кількості ушкоджених нервових волокон у нерві та аксонів із дегенеративними змінами (відсоток від загальної їх кількості) на напівтонких зрізах; а також площі набряку на гістологічних зрізах за допомогою сітки Автанділова [13]. Вимірювали також діаметр мієлінових нервових волокон. Статистичний аналіз цифрових даних виконували методами варіаційної статистики із застосовуванням t-критерію Стьюдента. Статистично значимою вважали різницю при $\mathrm{p}<0,05$.

\section{Результати досліджень та їх обговорення}

\section{Візуальний огляд}

На першу добу при візуальному огляді оперована кінцівка хибнооперованих тварин мала незначний набряк лише в ділянці розтину шкіри. Надалі набряк у кінцівці не відмічався. У тварин із трансплантацією драглистого ядра під нерв зафіксовано збільшення об'єму оперованої кінцівки. Набряк зберігався до 7-ї доби. На відміну від цього в тварин, яких лікували адалімумабом, незначний набряк оперованої кінцівки спостерігався лише до третьої доби.
Рана на шкірі в оперованих тварин всіх груп зажила первинним натягом на третю добу. Щури повністю навантажували кінцівку в усі терміни дослідження.

\section{Мікроскопічні дослідження}

Хибнооперовані тварини. 3-тя доба. У м'язовій тканині ділянки розтину шкіри відмічені незначні післятравматичні зміни. Спостерігається нерівномірне, місцями виражено базофільне забарвлення окремих м'язових волокон, що були роз'єднані за рахунок набряку. Міжпучкова пухка сполучна тканина незначно інфільтрована полінуклеарними, мононуклеарними та гістіоцитарними клітинами. Відмічаються поодинокі клітини фібробластичного диферону. В оболонках нерва та самому нерві дегенеративних змін не виявлено.

Через 7 діб у м'язовій тканині деструктивні зміни та явища запалення не відмічалися. У перимізії м'язових волокон має місце незначне збільшення клітин фібробластичного диферону та лімфоцитів. Місцями на невеликих ділянках розташовувались м'язові волокна 3 порушеними тинкторіальними властивостями - осередки нерівномірного забарвлення гематоксиліном.

Сполучна тканина ендоневрію, периневрію та епіневрію не виявляє ознак набряку та деструкції. У пухкій сполучній тканині оболонок спостерігаються судини - артеріоли, капіляри, венули з характерною для кожного типу судин стінками. Частина судин мала вузькі просвіти й не містили клітин крові, а деякі судини були заповнені кров’ю. Навколо судин не виявлено запальних інфільтратів.

ВГГСН зберігав характерну для норми структурну організацію. На аксіальних зрізах нерва визначаються мієлінові та безмієлінові нервові волокна круглястої та іноді овальної форми, розміщені без визначеного порядку серед більших за діаметром мієлінових волокон візуалізуються безмієлінові. Мієлінові волокна характеризуються рівномірною за товщиною мієліновою оболонкою.

На 15-ту добу після операції м'язова тканина та ВГГСН у ділянці розтину шкіри мали характерну для норми структурну організацію.

Тварини з трансплантацією драглистого ядра. 3-тя доба. У ділянці судинно-нервового пучка між м'язовою тканиною та пухкою сполучною тканиною, що оточує ВГГСН, виявляються фрагменти драглистого ядра з клітинами овальної та круглястої форми, які щільно контактують між собою й частково зберігають структуру синцитію. Клітини мають яскраво забарвлені гіпохромні ядра. Навколо залишків драглистого ядра виявляється виражений запальний процес, що зачіпає м'язову тканину, епіневрій та нерв.

У перимізії м'язової тканини, що оточує судиннонервовий пучок, спостерігається набряк, у зв'язку з чим м'язові волокна розташовані нещільно. Виявляється дифузна запальна інфільтрація та окремі периваскулярні іфільтрати.

У м'язових волокнах мають місце деструктивні зміни: порушення тинкторіальних властивостей, що виявляється нерівномірним забарвленням окремих м'язових волокон - від слабооксифільного до виражено базо- 
фільного; зміна форми волокон - поява ділянок стоншення, розширення та поздовжнього розпаду. Зустрічаються м'язові волокна з порушенням періодичності поперекової смугастості та частковою ії відсутністю.

Епіневрій, що оточує нерв по периметру, потовщений за рахунок набряку. Різнонаправлені пучки колагенових волокон епіневрію разшаровані, їх цілісність на ділянках порушена за рахунок розривів (рис. 1). Щільність фібробластів по ходу колагенових волокон нерівномірна, місцями значна. Окремі клітини мають пікнотичні ядра, відмічаються фібробласти з лізованим ядром. Між волокнами в пухкій сполучній тканині виявляються численні клітини запалення - лімфоцити, плазматичні клітини. 3'являються не характерні для інтактного нерва макрофаги, які частіше розташовуються периваскулярно. Збільшена щільність тканинних базофілів, що перебувають у стані часткової дегрануляції.

В епіневрії спостерігається значна щільність артеріол, капілярів та венул із відносно широкими просвітами неправильної форми. Деякі з них переповнені кров’ю. Кровоносні судини мають ознаки деструктивних змін. Відмічається пікноз ядер ендотеліальних клітин у капілярах та артеріолах, а також апоптоз клітин. Внутрішня еластична мембрана нерівномірної товщини, в окремих судинах - фрагментована. У просвіті деяких судин виявляються ендотеліоцити, що підтверджує наявність деструктивних змін внутрішньої еластичної мембрани.

Аналогічні описаним вище зміни спостерігаються і в сполучній тканині периневрію та ендоневрію, що оточують пучки нервових волокон та окремі волокна. Виявляється набряк (рис. 1). На окремих ділянках розташовуються скупчення клітин фібробластичного диферону різної зрілості, клітини запалення та поодинокі тканинні базофіли. Більша частина периневральних клітин має вакуолізовану цитоплазму, деякі клітини пікнотичні ядра.

Нервові волокна в пучках характеризуються варіабельністю за шириною, деякі з них набряклі. У незначної частини волокон структура мієліну порушена. Спостерігаються продукти розпаду мієлінових нервових волокон у вигляді дрібнозернистої субстанції. Щільність шванівських клітин у нерві нерівномірна, місцями знижена. Клітини мають численні вакуолі, окремі клітини - з лізисом ядра. Окремі безмієлінові нервові волокна також мають ознаки деструкції (рис. 2).

7-ма доба. Залишків драглистого ядра в ділянці його трансплантації на нерв не було виявлено, що свідчить про його розсмоктування. У ділянці трансплантації зберігаються відмічені на 3-тю добу явища набряку й виражені деструктивні зміни як у структурі м'язової тканини, так і в оболонках нерва, а також у самому нерві. Явища запалення, пов'язані з наявністю значної кількості лімфоцитів, плазматичних клітин та тканинних базофілів, збільшились порівняно з попереднім терміном. Не тільки відмічена більша кількість периваскулярних інфільтратів, але й розширились території самих інфільтратів.
Нервові волокна також зазнали значних деструктивних змін. Електронно-мікроскопічний аналіз показав, що більшість нервових волокон у нерві мають різного ступеня прояву деструкцію мієлінового шару. Визначаються нервові волокна з явищами набухання мієлінових оболонок, що супроводжується збільшенням їх діаметра. У частини нервових волокон виявляються осередки розшарування мієлінової оболонки, фрагментація та вакуолізація мієліну (рис. 3). Окремі волокна мають ділянки повної втрати мієлінового шару. Якісні зміни в мієліновій оболонці підтверджувались кількісними даними. Діаметр мієлінових нервових волокон був варіабельним - від 4 до 13 мкм, 3 переважанням малих та середніх розмірів. У середньому діаметр волокон дорівнював 7,8 \pm 0,5 мкм. У безмієлінових нервових волокнах відмічаються осередки розрідження та повного лізису нейрофіламентів у цитоплазмі відростків нейроцитів. У складі мієлінових волокон виявляється значна частина шванівських клітин із ядрами, які характеризуються високою долею гетерохроматину, що вказує на перебування таких клітин на етапах апоптозу. Окремі шванівські клітини містять ядро з розрідженим еухроматином та цитоплазму з ознаками набряку та низькою щільністю мембранних органел. Зрідка поблизу нервових волокон спостерігаються макрофаги 3 крупними вакуолями.

На підставі порівняння морфологічної ситуації в м'язовій тканині, оболонках нерва та нерві ділянки трансплантації драглистого ядра на даний термін із відміченими деструктивними змінами та явищами запалення на 3-тю добу можна стверджувати, що мала місце хронізація запального процесу.

15-та доба. У прилеглій до нерва м'язовій тканині спостерігаються ознаки хронічного запалення. Відмічається інфільтрація перимізію та ендомізію полінуклеарними, мононуклеарними та гістіоцитарними клітинами. На окремих ділянках міжм'язової пухкої сполучної тканини виражена проліферація фібробластів (рис. 4). М'язові волокна характеризуються відсутністю поперечної смугастості на окремих ділянках, нерівномірністю забарвлення та товщини по ходу волокна (рис. 4).

У периневрії та ендоневрії виявляється виражений міжволоконний набряк, на що вказує наявність крупних територій, заповнених набряковою рідиною. У таких ділянках колагенові волокна розшаровані. Окремі з них із деструктивними змінами. Щільність клітин в оболонках нерва залишається значною. Виявляються клітини фібробластичного диферону, лімфоцити, тканинні базофіли та окремі макрофаги. Спостерігається облітерація кровоносних судин, порушення цілісності шару ендотелію, що відбиває деструктивні зміни в капілярах. Відмічена дифузна інфільтрація оболонок клітинами запалення. Зустрічаються периваскулярні інфільтрати з дрібних лімфоцитів та плазматичних клітин. Більша частина вен і венул мають розширені просвіти й потовщені стінки, в артеріях та артеріолах просвіти звужені. Просвіти мікросудин залишаються розширеними. Як і на час попереднього спостереження, 
частина судин - з ознаками некротичних змін клітинних елементів.

У пучках нерва спостерігається деструкція значної частини нервових волокон - як мієлінових, так і безмієлінових. Нервові волокна мають варіабельний діаметр - від крупних до дрібних. Часто трапляються нервові волокна 3 нетиповою для норми формою. Відмічаються волокна неправильної, часом зигзагоподібної форми. Товщина мієлінового покриття також значно варіює. Виявляються численні крупно- та дрібнозернисті продукти розпаду покриття. Порівняно з хибнооперованими тваринами відмічається зменшення шванівських клітин. Шванівські клітини та макрофаги мають крупні вакуолі. В окремих пучках нервових волокон лише місцями відмічені поодинокі дрібні новоутворені аксони.

Виконаний морфометричний аналіз показав, що відсоток нервових волокон із деструктивними змінами у тварин даної дослідної групи становить 72,6 \%, а площа, яку займає набряк епі- та периневрію, становить $58,8 \%$.

Одноразове лікування тварин адалімумабом. 3-тя доба. У прилеглій до ділянки трансплантації м'язовій тканині поблизу залишків драглистого ядра виявляються ознаки запалення та незначні деструктивні зміни. Незначні деструктивні зміни, пов'язані з порушенням тинкторіальних властивостей, спостерігались лише в окремих м'язових волокнах, на відміну від тварин попереднього досліду. Порівняно з нелікованими тваринами деструктивні зміни в м'язовій тканині та запальний процес у ділянці трансплантації драглистого ядра на ВГГСН були меншими, про що свідчить низька щільність клітин запалення в перимізії та оболонках нерва.

У сполучній тканині оболонок нерва - епіневрію, периневрію та ендоневрію - виявляється набряк, у зв'язку з чим їх волокниста строма розшарована. Незначна частина колагенових волокон має деструктивні зміни. Між волокнами спостерігається нерівномірна щільність клітин фібробластичного диферону, невеликі скупчення лімфоцитів та плазматичних клітин. Серед фібробластів відмічені клітини з пікнотичними ядрами та клітини-тіні. В епіневрії відмічаються поодинокі периваскулярні інфільтрати.

Нервові волокна в пучках мають різні діаметри. Мiєлінова оболонка незначної частини нервових волокон ушкоджена та фрагментована, з чим пов'язана варіабельність товщини та зміна контурів волокон. Відмічається різного ступеня деструкція мієлінового шару. В окремих мієлінових волокнах на фоні відносно добре збереженого мієлінового шару наявна деструкція осьових циліндрів.

7-ма доба. Залишків драглистого ядра в ділянці його трансплантації не відмічено, проте простежуються ознаки незначного запалення в м'язовій тканині, пухкій сполучній тканині, що оточує судинно-нервовий пучок, периневрії та ендоневрії, а також зміни структури нерва. Кровоносні капіляри в оболонках нерва без ознак тромбозу, однак у деяких капілярах епіневрію має місце стаз крові.
На більшій частині території м'язової тканини спостерігається щільне розташування м'язових волокон, що зберігають характерну для норми структурну організацію, і лише на невеликих ділянкам м'язові волокна упаковані пухко. Це свідчить про наявність незначного набряку в м'язовій тканині. Місцями відмічені ділянки м'язових волокон зі зменшеною щільністю клітин та деструктивними змінами окремих міоцитів. Поміж м'язових волокон розташовуються поодинокі периваскулярні інфільтрати з клітин запалення.

Дослідження ультраструктурної організації ВГГСН щурів свідчить про наявність ознак запалення в периневрії лише окремих пучків нервових волокон. Набрякова рідина поміж пучками колагенових волокон практично не визначається. У нервовому стовбурі ВГГСН серед крупних мієлінових нервових волокон відмічаються безмієлінові волокна, що розташовуються без певного порядку, як поодинокі, так і кабельного типу. В окремих безмієлінових волокнах відмічаються осередки деструкції. Більша частина мієлінових волокон зберігає структурну організацію, характерну для норми (рис. 6). Зрідка поблизу нервових волокон спостерігаються окремі шванівські клітини (рис. 6) та бюнгнерівські стрічки - проліферати шванівських клітин, що є відображенням локальних процесів репарації нерва $[15,16]$. Відмічено незначне збільшення порівняно 3 контрольними щурами середнього діаметра мієлінових нервових волокон $-9,3 \pm 0,6$ мкм, що обумовлено, на нашу думку, зменшенням деструктивних змін у мієліновій оболонці.

15-та доба. У ділянці трансплантації драглистого ядра спостерігаються незначні явища запалення в перимізії м'язової тканини та пухкій сполучній тканині оболонок нерва. Лише на незначних територіях виявляються невеликі скупчення клітин запалення. Значно меншими були й деструктивні зміни в нерві.

Виконані морфометричні дослідження свідчать про те, що нервові волокна з дегенеративними змінами в нерві становлять $20,3 \%$, що у 3,8 раза $(\mathrm{P}<0,001)$ менше за показники в нелікованих тварин. Площа, яку займав набряк епі- та периневрію, у лікованих тварин, становить $23,7 \%$, що в 2,48 раза $(\mathrm{P}<001)$ менше за показники тварин без лікування.

Морфометричні дані, доповнюючи результати гістологічного та електронно-мікроскопічного аналізу, свідчать, що адалімумаб значно знижує прояви запалення та сприяє збереженню структури нерва.

Дворазово проліковані тварини. 7-ма доба. При гістологічному дослідженні виявлено, що запальний процес у ділянці трансплантації був слабко виражений i простежувався тільки в периневральних тканинах м'язовій та сполучній (рис. 5). Поміж м'язових волокон розташована незначна кількість лімфоцитів та веретеноподібних клітин фібробластичного диферону, з переважанням останніх. Відмічається зменшення загальної інфільтрації. У м'язовій тканині зафіксовані осередки м'язових волокон із порушеними тинкторіальними властивостями. Лише місцями в окремих м'язових волокнах виявляються ділянки з невираженою поперековою смугастістю. 


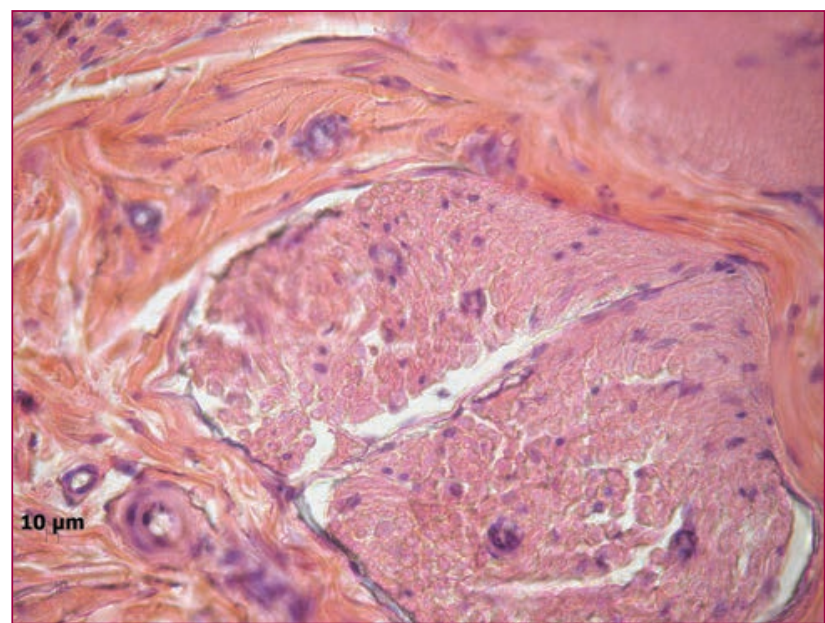

Рисунок 1. Нерв із ділянки трансплантації драглистого ядра. Епіневрій та периневрій із розшарованими пучками колагенових волокон. Виражений набряк ендоневрію. Гематоксилін та еозин. Ок. 10, об. 100

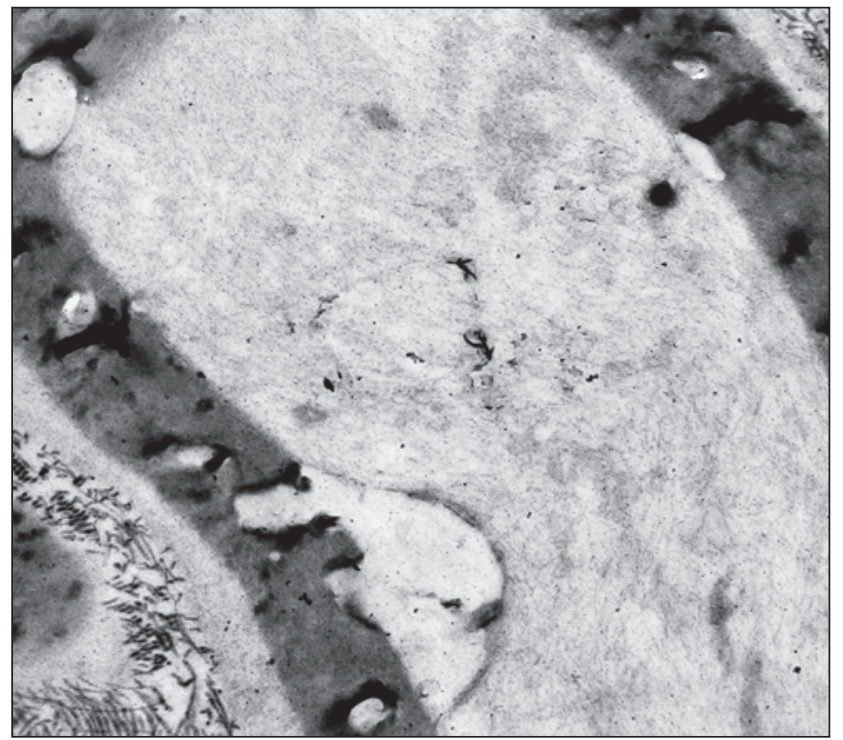

Рисунок 3. Вакуолізація та осередки лізису мієлінової оболонки нервового волокна.

Контрастування за Рейнольдсом, х 15600

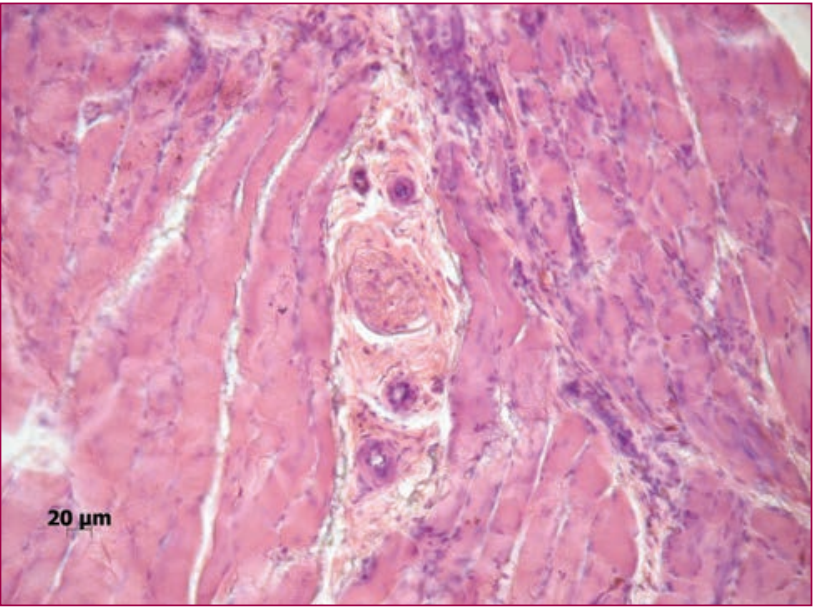

Рисунок 5. Слабо виражений запальний процес м'язової тканини у діляниі нерва з трансплантацією драглистого ядра. Гематоксилін та еозин. Ок. 10, об. 20

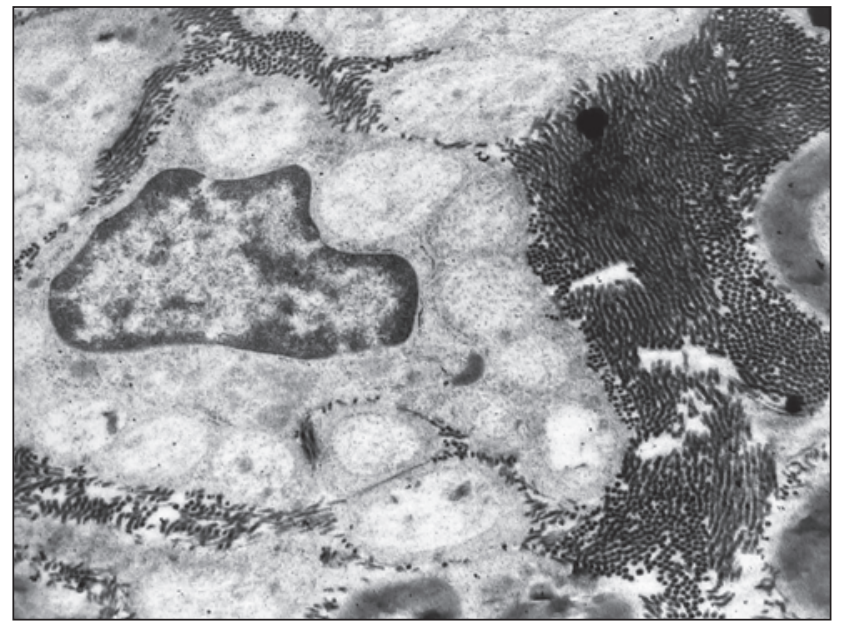

Рисунок 2. Шванівська клітина та численні безмієлінові волокна кабельного типу. Осередки деструкиії в окремих безмієлінових волокнах.

Контрастування за Рейнольдсом, х 6000

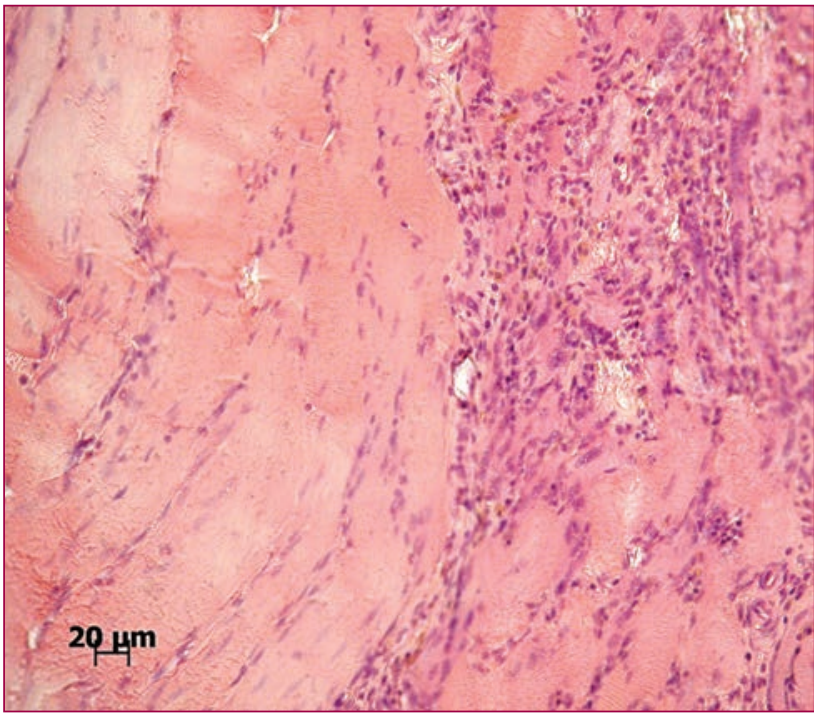

Рисунок 4. Ділянка м'язової тканини із зони транспланта ції драглистого ядра. Деструкція м'язових волокон, відсутність поперечної смугастості, висока щільність фібробластів на ділянках. Гематоксилін та еозин. Ок. 10, об. 20

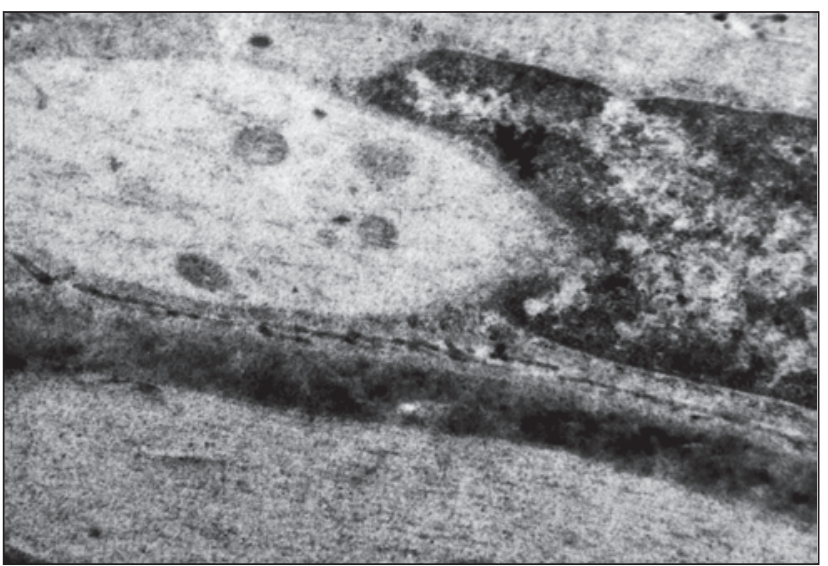

Рисунок 6. Шванівська клітина поруч із безмієліновим волокном. Фрагмент поздовжньо орієнтованого мієлінового волокна типової ультраструктури. Контрастування за Рейнольдсом, х 20400 


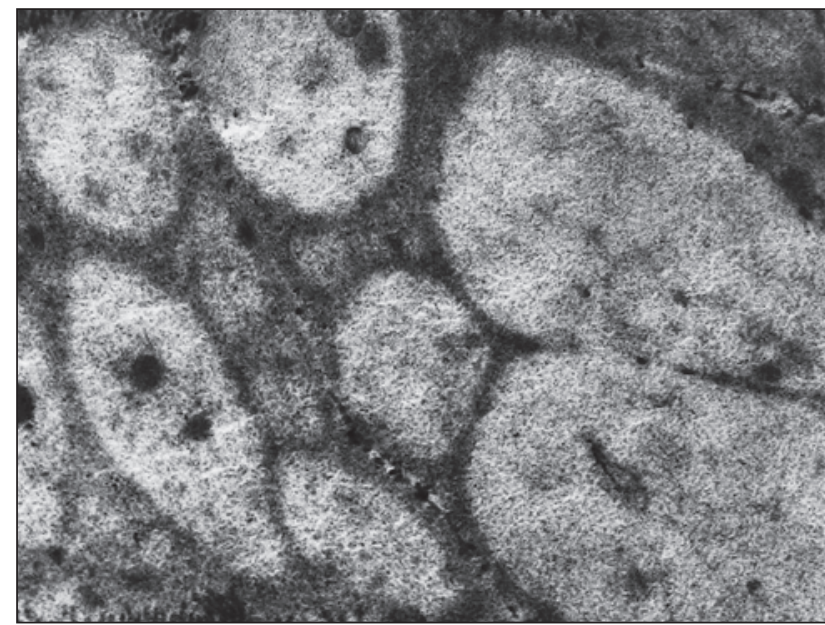

Рисунок 7. Скупчення варіабельних за діаметром безмієлінових волокон типової організації. Контрастування за Рейнольдсом, х 20400

В епіневрії відмічаються різнонаправлені пучки колагенових волокон, між якими щільність клітин фібробластичного диферону була рівномірною. Клітини запалення не спостерігаються. Щільність кровоносних судин різного калібру в ділянці судиннонервового пучка помірна, більша частина 3 них мала характерну організацію. Лише в поодиноких випадках виявлялися капіляри та артеріоли з тромбозом як наслідок прояву запального процесу до введення адалімумабу.

При дослідженні структури нерва було виявлено переважання територій без набряку, лише на окремих ділянках він був слабо вираженим. Аналіз ультраструктурної організації ВГГСН щурів, які отримали 2-кратне введення адалімумабу, показав, що в периферичному нерві переважали мієлінові волокна типової ультраструктури. Вони були розташовані на близькій відстані одне від одного, мали варіабельної товщини шар мієліну, що характеризувався високою електронною щільністю та практично не містив ознак деструкції (рис. 6). Лише окремі мієлінові волокна мали осередки гомогенізації мієлінового шару. Саме зі значним зменшенням деструкції мієлінового шару в нервових волокнах пов'язані вірогідно більші діаметри (13,4 \pm 1,3 мкм) мієлінових нервових волокон у тварин даної серії порівняно $з$ контролем. Порівняно з результатами попереднього досліду в нервових волокнах збільшена кількість аксонів із колбами росту. На ділянках спостерігалася проліферація шванівських клітин з фестончатим ядром та 1-2 крупними ядерцями (рис. 7). Місцями серед нервових волокон розташовуються проліферати шванівських клітин (бюнгнерівські стрічки). У тварин даної серії відмічається збільшення діаметра бюнгнерівських стрічок. Лише в деяких шванівських клітинах виявляється гетерохроматизація клітинного ядра та локальний лізис ядерної й цитоплазматичної мембрани. Окремі шванівські клітини містили в цитоплазмі скупчення варіабельних за розмірами та формою вторинних лізосом.

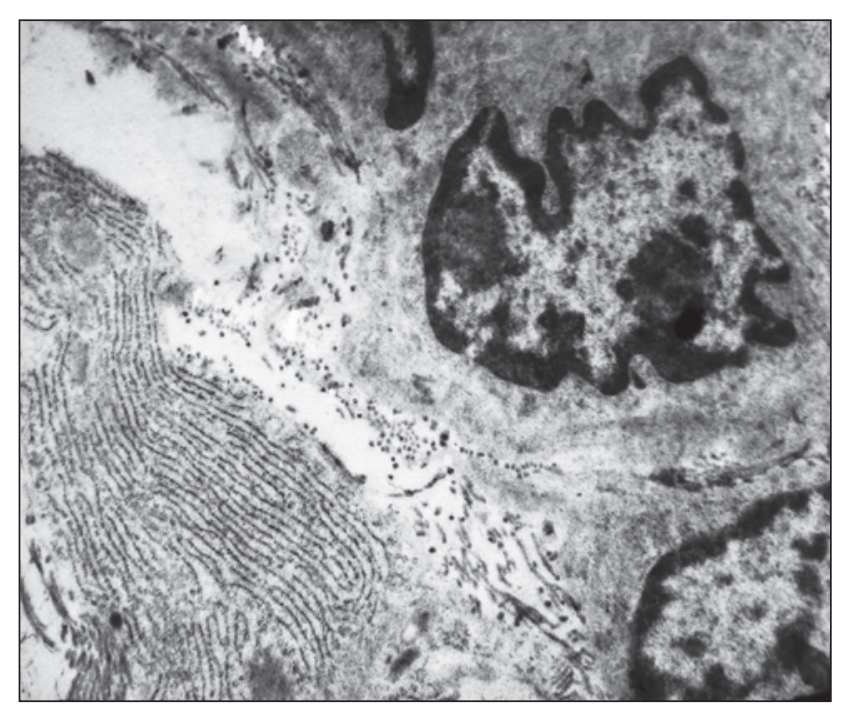

Рисунок 8. Проліферація шванівських клітин. Ядро шванівської клітини з двома крупними ядерцями. Контрастування за Рейнольдсом, х 15600

Безмієлінові волокна мали типову ультраструктурну організацію (рис. 8). Окремі волокна містили ознаки деструкції - розрідження цитоплазми та осередки лізису цитоплазматичної мембрани.

15-та доба. М'язова тканина в ділянці трансплантації драглистого ядра практично не мала деструктивних змін. На невеликих ділянках спостерігалось нерівномірне забарвлення гематоксиліном м'язових волокон та незначне збільшення клітин фібробластичного диферону в перимізії. Окремі м'язові волокна мали порушення періодичності поперекової смугастості.

Ознаки набряку та прояви запалення в оболонках нерва порівняно $з$ нелікованими тваринами були значно меншими, а щодо одноразово пролікованих практично були аналогічними. В епіневрії відмічається дещо підвищена порівняно з хибнооперованими тваринами кількість фібробластів. Лише подекуди поблизу кровоносних судин спостерігаються периваскулярно клітини та поодинокі макрофаги. Окремі епіневральні кровоносні судини мають потовщені стінки та розширені просвіти. Периневрій та ендоневрій зберігають цілісність та характерну структуру. Ендоневральні мікросудини без виражених деструктивних змін. Більшість м'якотних та безм'якотних нервових волокон зберігають нормальну структуру. Навколо частини нервових волокон відмічається активна проліферація шванівських клітин. Лише окремі м'якотні нервові волокна мають ознаки дегенерації.

Виконаний морфометричний аналіз кількості нервових волокон з деструктивними змінами та площі, що займає набряк, показав, що відсоток нервових волокон з деструктивними змінами становить 15,8 \%, а площа набряку $-13,6 \%$. Встановлені показники були меншими у 4,6 та 4,3 раза від визначених у контрольних тварин. Порівняно з одноразово лікованими тваринами також відмічається зменшення, проте не таке виражене - відсоток волокон з деструктивними змінами був меншим в 1,3 раза, а площа набряку зменшилась в 1,7 раза. 


\section{Обговорення одержаних результатів}

У виконаному дослідженні встановлено, що проведення тільки оперативного втручання з розтином шкіри, розведенням м'язів у проекції ВГГСН та відокремлення його від м'язів не призводить до розвитку значних деструктивних змін та явищ запалення в згаданих тканинах. Незначні післятравматичні зміни спостерігаються в м'язовій та периневральній сполучній тканині лише на 3-тю добу.

Виражений набряк, деструктивні зміни та явища запалення в м'язовій тканині, оболонках нерва та нерві відмічені в тварин, яким трансплантували драглисте ядро на нерв. Виявлені порушення в нерві проявлялися вже на 3-тю добу й зберігалися до 15-ї доби. Ми пов'язуємо їх розвиток з наявністю в периневральній ділянці нерва драглистого ядра, що виявляє здатність навіть в ектопічних умовах синтезувати прозапальні цитокіни [14 ].

Результати проведеного дослідження свідчать про ефективність одноразового та дворазового застосування антагоніста фактора некрозу пухлини альфа - адалімумабу в умовах експериментально змодельованого запального процесу в периферичному нерві та периневральних тканинах. Її проявом є зниження інтенсивності запального процесу в нерві, периневральній пухкій сполучній та м'язовій тканинах. Зниження запального процесу та набряку в периневральних тканинах сприяє затримці деструкції нервової тканини. Деструктивні зміни, що відбулися в периферичному нерві на фоні впливу ФНП- $\alpha$ (після трансплантації автологічного драглистого ядра щурів до великогомілкової гілки сідничного нерва), хоча й мали місце, однак були значно меншими порівняно з контрольною нелікованою групою щурів. У тварин, яких лікували, більша частина нервових волокон зберігає характерну організацію мієлінової оболонки. Поряд зі зниженням інтенсивності деструктивного процесу мали місце репаративні прояви, а саме формування безмієлінових та мієлінових волокон із різним ступенем мієлінізації. Підтвердженням цьому є дані літератури, що вказують на ефективність пригнічення продукції ФНП- $\alpha$ при лікуванні пацієнтів із хронічним резистентним до лікування дискогенним болем [5]. На протекторну роль селективного пригнічення індукованого драглистим ядром біосинтезу ФНП- $\alpha$ в дегенерації дорзальних корінців нервових гангліїв вказували Y. Murata та співaвT. (2004) [14].

\section{Висновки}

1. Трансплантація автологічного драглистого ядра на ВГГСН у шурів призводить до набряку та розвитку вираженого запального процесу як у м'язовій тканині, так і в оболонках нерва (епі-, пери- та ендоневріi), що з часом хронізується. У нерві відмічаються виражені деструктивні зміни, переважно в м'якотних нервових волокнах.

2. Доведена ефективність одноразового та дворазового використання антагоніста фактора некрозу пухлини альфа - адалімумабу в умовах експериментально змодельованого запального процесу в периферичному нерві та периневральних тканинах щурів при трансплантації автологічного драглистого ядра на ВГГСН, про що свідчить зниження інтенсивності запального процесу в епі-, пери-, ендоневральних тканинах та збереження ультраструктурної організації мієлінових та безмієлінових волокон у більшій частині нервових пучків ВГГСН. Більший ефект лікування досягається при застосуванні дворазового введення адалімумабу.

Автори статті висловлюють подяку науковому співробітнику лабораторії експериментального моделювання Г.В. Іванову за допомогу у виконанні оперативних втручань на иурах.

\section{Список літератури}

1. Olmarker K. Pathogenesis of sciatic pain. A study of spontaneous behavior in rats exposed to experimental disc herniation / K. Olmarker, R. Storkson, O.G. Berge // Spine. 2002. - Vol. 27. - P. 1312-1317.

2. Chronic inflammation and compression of the dorsal root contribute to sciatica induced by the intervertebral disc herniation in rats / S.X. Hou, J.G. Tang, H.S. Chen, J. Chen // Pain. 2003. - Vol. 105. - P. 255-264.

3. Comparison of neuropathic pain induced by the application of normal and mechanically compressed nucleus pulposus to lumbar nerve roots in the rat / M. Kawakami, H. Hashizume, H. Nishi [et al.] // J. Orthop. Res. - 2003. - Vol. 21. - P. 535539.

4. Nerve growth factor involvement in pain behavior in a rat model of experimental disc herniation / A. Onda, Y. Murata, B. Rydevik et al.: $31^{\text {st }}$ annual meeting of the International Society for the Study of the Lumbar Spine. - 2004.

5. Tobinick E. L. Perispinal TNF-alpha inhibition for discogenic pain / E.L. Tobinick, S. Britschgi-Davoodifar // Swiss Med. Wkly. - 2003. - Vol. 133. - P. 170-177.

6. European Medicines Agency. Assessment report. Humira. Adalimumab. - 2012. - P. 1-62.

7. Дєдух Н.В. Вплив драглистого ядра міжхребцевого диска на великогомілкову гілку сідничного нерва / Н.В. Дєдух,
С.В. Малишкіна, М.В. Шимон // Український журнал клінічної та лабораторної медицини - 2011. - Р. 48-52.

8. Європейська конвенція про захист хребетних тварин, що використовуються для дослідних та інших наукових цілей. Страсбург, 18 березня 1986 року: офіційний переклад [Електронний ресурс] / Верховна Рада України. - Офіц. вебсайт. - (Міжнародний документ Ради Європи). - Режим доступу до документа: http: zakon.rada.gov.ua/cgi-bin/laws/main. cgi?nreg=994_137.

9. Закон У тварин від жорстокого поводження» (Стаття 26).

10. Саркисов Д.С. Микроскопическая техника / Д.С. Саркисов, Ю.Л. Перова. - М.: Медицина, 1996. - 542 с.

11. Уикли Б. Электронная микроскопия для начинающих / Б. Уикли. - М.: Мир, 1975. - 324 с.

12. Reynolds E.S. The use of lead citrate at high ph an electrono-paque stain in electron microscopy / E.S. Reynolds // J. Cell Biol. - 1963. - Vol. 17. - P. 208-212.

13. Автандилов Г.Г. Медицинская морфометрия: [руководство] / Г.Г. Автандилов. - М.: Медицина, 1990. - 384 с.

14. Selective inhibition of tumor necrosis factor-alpha prevents nucleus pulposus-induced histologic changes in the dorsal root ganglion / Murata Y., Onda A., Rydevik B. et al. // Spine (Phila Pa 1976). - 2004. - Vol. 29, № 22. - P. 2477-2484.

Отримано 14.03.13 
Дедух Н.В., Радченко В.А., Бенгус Л.М., Малышкина С.В., Шимон М.В.

ГУ «Институт патологии позвоночника и суставов им. проф. М.И. Ситенко НАМН Украины», г. Харьков

\section{Морфология периферического нерва крыс в зоне трансплантации аутологичного студенистого ядра после терапии адалимумабом}

Резюме. Морфологический анализ структурной организации большеберцовой ветви седалищного нерва крыс в зоне трансплантации аутологичного студенистого ядра после проведенного лечения адалимумабом показал, что у животных наблюдались снижение интенсивности воспалительного процесса в эпи-, пери-, эндоневральних тканях и значительно лучшая сохранность ультраструктуры миелиновых и безмиелиновых волокон в периферическом нерве при сравнении с крысами контрольной нелеченой группы.

Ключевые слова: периферический нерв, студенистое ядро, трансплантация, адалимумаб, метаболические показатели сыворотки крови.
Dedukh N.V., Radchenko V.A., Bengus L.M., Malyshkina S.V., Shimon M.V.

State Institution «Institute of Spine and Joint Pathology named after professor M.I. Sytenko of National Academy of Medical Sciences of Ukraine», Kharkiv, Ukraine

\section{The Morphology of Peripheral Nerve of Rats in the Area of Transplantation Of Autologous Nucleus Pulposus after Treatment with Adalimumab}

Summary. Morphological analysis of the structural organization of the tibial branch of the sciatic nerve of rats in the area of transplantation of autologous nucleus pulposus after treatment with adalimumab showed that in animals there had been observed decrease in the intensity of the inflammatory process in the epi-, peri-, endoneural tissues and significantly better preservation of ultrastructure of myelin and non-myelinated fibers in the peripheral nerve when compared with the untreated control group rats.

Key words: peripheral nerve, nucleus pulposus, transplantation, adalimumab, blood serum metabolic indexes. 